\title{
Non-Index Lesion
}

National Cancer Institute

\section{Source}

National Cancer Institute. Non-Index Lesion. NCI Thesaurus. Code C110962.

Any tumor lesion other than the largest tumor lesion targeted by therapy. 